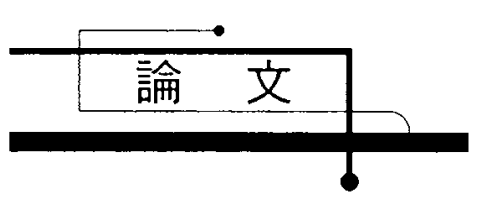

\title{
垂直上昇多分岐管における気液二相分配 *
}

\author{
Gas-Liquid Flow Distribution in Multi-Pass Upward Channels
}

\section{ズラズマン・ラズラン **五 島宏 明**廣 田真 史 ${ }^{* *}$ 水 野 安 浩 ${ }^{* * *}$ ZURADZMAN M.R. GOSHIMA Hiroaki HIROTA Masafumi MIZUNO Yasuhiro}

\author{
丸山直 樹 ${ }^{* *}$ 西村 顕 ${ }^{* *}$ 磯 部 僚 太十 \\ MARUYAMA Naoki NISHIMURA Akira ISOBE Ryota
}

\begin{abstract}
The gas-liquid flow distributions in the multi-pass upward channels that simulated the compact evaporators for the automobile air-conditioning system were investigated experimentally. Special attention was directed to influences of the inlet flow pattern at the header entrance, pressure condition at the branch outlets, and pressure-loss characteristics of branches on the gas-liquid distributions. Experiments were conducted in an isothermal air-water flow system. It was found that the pressure condition at the branch outlets exerted a great influence on the gas-liquid distributions to branches when flat smooth tubes were adopted as branches, but it had a minor influence when the branches consisted of multi-port tubes. The inlet flow pattern at the header entrance had a significant influence on the gas-liquid distribution, and liquid tended to be distributed to all the branches when the inlet flow pattern is a mist flow.
\end{abstract}

Keywords: Gas-liquid flow distribution, Multi-pass channel, Inlet-flow pattern, Outlet pressure, Multi-port tube

\section{1. 緒 言}

自動車用空調システムに使用されるコンパク トエバポレータでは、高性能化や小型化を目的と して冷媒を主管 (ヘッダ) から複数の流路に分岐 させる多分岐管が多く用いられている[1]。こうし た多分岐管内の流れが気液二相流の場合には、各 分岐管への気液分配が不均等になり機器の性能 低下をもたらすおそれがある。そのため、多分岐 管内の気液二相流においてへッダから分岐管へ の分配特性を明らかにすることは工学的に重要 であり、これまで多くの研究が行われている [2-14]。ヘッダから分岐管への気液分配特性は、 ヘッダ内の流動様式や圧力分布など多くの要素 に依存して変化する[14]。こうしたパラメータが
気液分配に及ぼす影響について調査することは、 エバポレータにおいて理想的な分岐管への気液 均等分配を実現するためにも重要と考えられる。 しかし、多分岐管における気液分配機構は複雑で ありパラメータも多岐にわたるため、系統的な知 見は必ずしも十分ではないように思われる。そこ で本研究では、分岐管への気液分配に大きな影響 を及ぼすと考えられる(1)ヘッダ内の流動様式、

(2) 分岐管出口の圧力条件、(3) 分岐管の圧力損失 特性、に注目し、エバポレータ実機を模擬した垂 直上昇多分岐管内の気液二相流について、これら が気液分配特性に及ぼす影響を実験的に検討し た。実験においては、冷媒二相流を基本的な流動 状態の把握に適した空気一水二相流によって模

\footnotetext{
* 2010.11.26 受付

** 三重大学大学院工学研究科機械工学専攻 干514-8507 三重県津市栗真町屋町 1577

TEL: (059)231-9385 FAX: (059)231-9385 E-mail: hirota@mach.mie-u.ac.jp

*** (株) デンソー 熱交換器開発部

$\dagger$ 中部電力 (株) 浜岡原子力発電所
} 


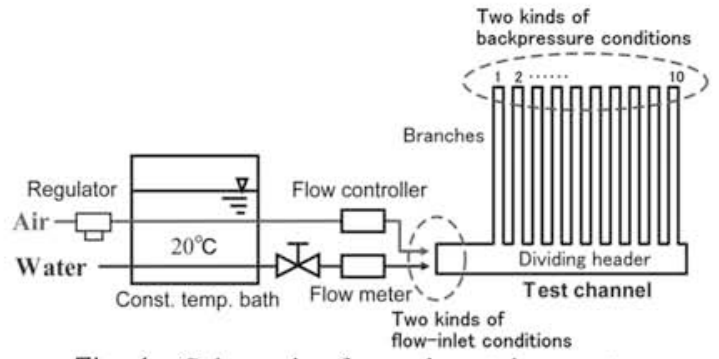

Fig. 1 Schematic of experimental apparatus.

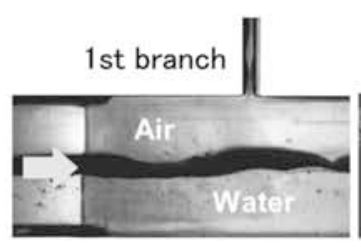

(a) Stratified-flow inlet

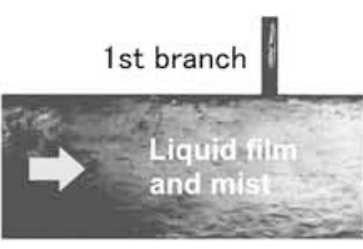

(b) Mist-flow inlet
Fig. 2 Flow-inlet conditions at the header entrance.

擬し、各分岐管への気液分配率に加えてヘッダ内 の圧力分布老測定して、分岐管出口の圧力条件に ついても検討を加えた。

\section{2. 実験装置および実験方法}

Fig. 1 に流路系の概要寺示寸。空気と水は恒温 水槽で $20^{\circ} \mathrm{C}$ に調整後、流量計を経て試験流路に 流入する。試験流路は自動車用エバポレータを模 擬しており、断面 $20 \mathrm{~mm} \times 20 \mathrm{~mm}$ 、長さ $255 \mathrm{~mm}$ の 水平へッダ (Dividing header) に、断面 $20 \mathrm{~mm} \times 2 \mathrm{~mm}$ 、 長さ $200 \mathrm{~mm}$ の偏平断面をもつ平滑管（偏平分岐 管と記す）が鉛直上向きに $20 \mathrm{~mm}$ 間隔で 10 本接 続されている。最上流の第 1 分岐管はへッダ入口 の $55 \mathrm{~mm}$ 下流に位置し、第 10 分岐管の下流側に は $20 \mathrm{~mm}$ の直線部分が設けられている。

本研究では、ヘッダ内の流動様式、分岐管出口 の圧力条件、分岐管の圧力損失特性を変化させて、 気液分配特性を調查した。まず、ヘッダ内の流動 様式が気液分配に及ぼす影響について検討する ために、本研究ではFig. 2 に示す 2 種類のヘッタ 入口流入条件について実験を行った。Fig. 2(a) は 気液が上下に分離した状態でヘッダに流入する

「層状流入」、Fig. 2(b) は液が微小液滴状になっ て流入する「噴霧流入」であり、ヘッダ入口近傍 の流動状態を示している。前者では、ヘッダ上流 に不織布製エアフィルタを充填させた流路 (断面 $20 \mathrm{~mm} \times 20 \mathrm{~mm}$ 、長さ $300 \mathrm{~mm}$ ) を接続し、空気と水 を別々の流入孔から供給することでヘッダに入

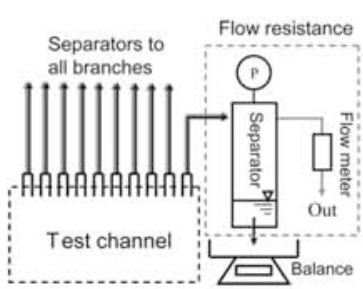

(a) Case $\mathrm{A}$

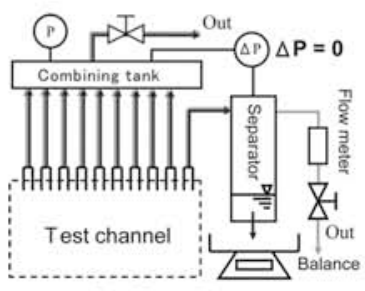

(b) Case B
Fig. 3 Pressure conditions at the branch outlets.

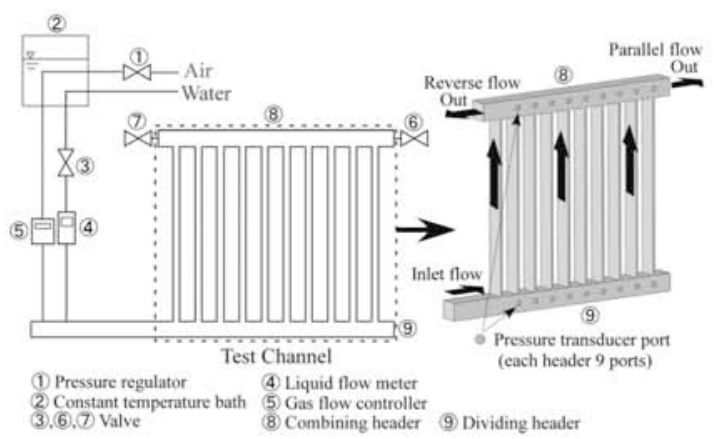

Fig. 4 Apparatus for pressure measurement in headers.

る流れを層状流とした。この場合、ビデオ画像か ら求めたへッダ入口直前における平均ボイド率 は約 $0.5 \sim 0.6$ であった。また、この助走流路の出 口付近に圧力センサを取り付け、ヘッダ入口直前 の圧力を測定した。後者では、ヘッダ入口に二流 体ノズル (スプレーイングシステムズジャパン、 二流体エアーアトマイジングノズル、SU4）を設 置して噴霧流を形成した。この二流体ノズルは、 粒径 $10 \mu \mathrm{m} \sim 70 \mu \mathrm{m}$ 程度の微小液滴を発生させる ことができる。

次に、分岐管出口の圧力条件が気液分配に及ぼ 寸影響を調べるために、本実験ではFig. 3 に示寸 2 種類の方法で気液分配率老測定した。Case A で は全分岐管の出口にそれぞれ気液セパレータと 気体流量計を接続し、10 本の分岐管における気 液分配率とセパレータ内の圧力を同時に測定し た。この場合、分岐管出口にはセパレータ内と同 等の圧力がかかり、その值はセパレータを通過す る流量に応じて変化するため、後述のように分岐 管出口の圧力分布は不均一になる (不均一背圧)。 一方、Case B では計測対象とする 1 本の分岐管の みを気液セパレータと気体流量計に接続し、他の 分岐管は合流タンクに接続する。セパレータと合 流タンクの出口に設置されたバルブを調節して、 両者の圧力差を零とする。合流タンクは十分大き 
く内部の圧力は一定であることを確認したため、 Case B では全分岐管にかかる背圧を等しくした 状態で、各分岐管への気液分配を測定することが 可能となる (均一背圧)。なお、従来の多分岐管 における気液分配の研究では、Case A に相当する 測定方法が多く用いられている。

また、自動車用エバポレータでは、冷媒流路に 偏平微細多孔管[15]が多く使用されている。この 管を分岐管に用いた場合、細孔を有しない偏平管 とは圧力損失特性が異なるため、気液分配にも影 響が及ぶと予想される。そこで本研究では、偏平 分岐管に加えて、偏平微細多孔管を分岐管に用い た場合（多孔分岐管）についても実験を行い、分 岐管の圧力損失特性が気液分配に及ぼす影響に ついて検討した。本実験で用いた微細多孔管は、 自動車用エバポレータの実機に使用されている アルミチューブであり、断面 $17 \mathrm{~mm} \times 1.8 \mathrm{~mm}$ 、長さ $200 \mathrm{~mm}$ の偏平管内に 12 の矩形断面流路（断面 $1 \mathrm{~mm} \times 0.8 \mathrm{~mm} ）$ と $2 つ$ 三角形断面流路が設けら れている。同一流量の単相流の場合、本偏平微細 多孔管の圧力損失は偏平管の約 25 倍であった。

エバポレータ実機では分岐管下流にもへッダ

(Combining header) が設けられている。本研究 では、Fig. 4 に示すように分岐管下流にも上流側 と同寸法のヘッダを設けた状態でヘッダ内の圧 力分布を測定し、分岐管の背圧条件について検討 した。測定点は各ヘッダ側面の分岐管直上と直下 に相当する位置に設け、シリコンオイル封入を施 した半導体圧力センサで 1 分間の時間平均圧力 を測定した。なお、本実験では、ヘッダ出口がへ ッダ入口と同じ側にある Reverse flow と、反対側 にある Parallel flow について測定を行った。

いずれの条件においても、各分岐管内の気相流 量はセパレータに接続した気体流量計で、また液 相流量はセパレータ内に一定時間貯めた水の質 量を測定することにより求めた。空気と水の流入 速度条件はエバポレータ実機における冷媒各相 の平均流速に一致させ、ヘッダ入口における気相 見かけ速度 $j_{g}=1.0 \sim 5.0 \mathrm{~m} / \mathrm{s}$ 、液相見かけ速度 $j_{l}=$ $0.015 \sim 0.045 \mathrm{~m} / \mathrm{s}$ の範囲で実験を行った。

\section{3. 実験結果および考察}

\section{1 層状流入の実験結果}

最初に、ヘッダへの流入条件を層状流入に固定 した条件下で、分岐管出口の圧力条件が気液分配

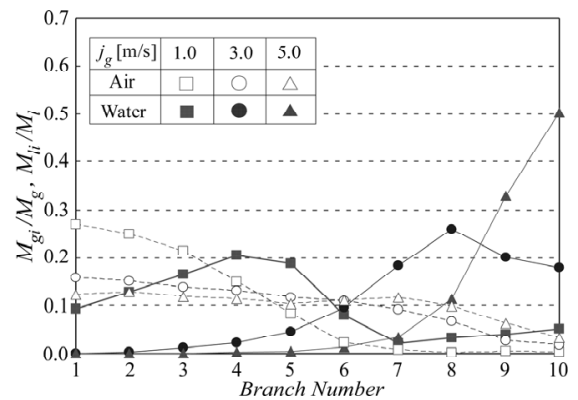

(a) Case A

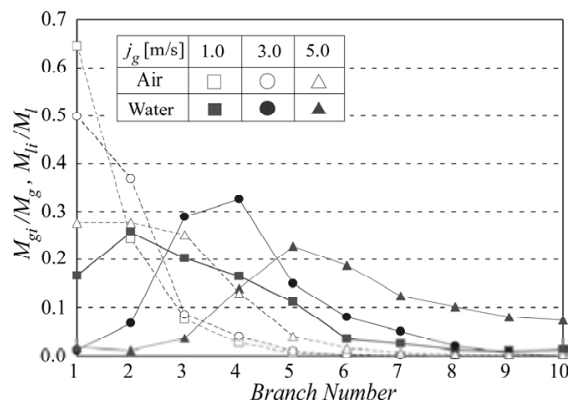

(b) Case B

Fig. 5 Flow distributions for stratified-flow inlet (Flat tube branches, $j_{l}=0.03 \mathrm{~m} / \mathrm{s}$ ).

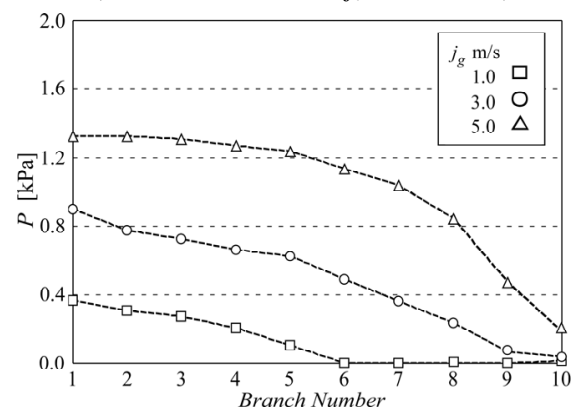

Fig. 6 Pressure distributions at branch outlets.

に及ぼす影響について調べた結果を示す。Fig. 5 は、偏平分岐管における気液分配率であり、(a) は分岐管出口圧力が不均一になる Case A (不均一 背圧、Fig. 3(a)の測定条件)、(b)は分岐管出口圧 力を均一にした Case B（均一背圧、Fig. 3(b)）に おける代表的な測定結果である。図の横軸は分岐 管番号であり、下流に位置する分岐管ほど番号が 大きくなる。縦軸は各管の気相質量分配率 $M_{g i} / M_{g}$ （破線）と液相質量分配率 $M_{l i} / M_{l}$ (実線) である。 図には液相見かけ速度 $j_{l}$ を $0.03 \mathrm{~m} / \mathrm{s}$ に固定し、気 相見かけ速度 $j_{g}$ を変化させた場合について示し た。また、Fig. 6 は Case A で測定された分岐管 
出口の圧力分布である。圧力は最上流の分岐管で 最大值を示し、下流に向からにつれて低下してお り、Case A では分岐管出口において不均一な背圧 分布が形成されていることが確認できる。

Case A の場合、 $j_{g}=1 \mathrm{~m} / \mathrm{s}$ と低気相速度では、気 相は上流側の分岐管ほど多く分配され、第 6 分岐 管より下流では $M_{g i} / M_{g}$ はほぼ零となる。また、 液相も同様に上流側分岐管に多く分配されるが、 気相とは異なり第 4 分岐管で $M_{l i} / M_{l}$ は最大にな る。この位置はへッダ内で波が成長し液がヘッダ 上壁に到達する位置に対応しており、波により液 相が非定常的に分岐管へ流入する様子が観察さ れた。下流域では気液分配率は非常に低くなり、 流れが停滞状態にあることが分かる。この場合、 ヘッダの下流部分には液が充満していた。

$j_{g}$ の増加に伴い気相は下流域の分岐管にも分配 されるようになり、 $j_{g}=5 \mathrm{~m} / \mathrm{s}$ では第 8 分岐管に至 るまで $M_{g i} / M_{g}$ はほぼ均等の值を示している。こ れは、 $j_{g}$ の増加により気相の慣性力が大きくなる ため上流側分岐管への分配率が下がる一方、下流 域では流量の減少に伴い慣性力も低下し、分岐管 一流入し易くなるためと考えられる[14]。こうし た気相分配の傾向は、Fig. 6 の圧力分布と良い相 関を示している。一方、液相分配は $j_{g}$ の増加に伴 い下流側の分岐管へ偏るようになる。これは、気 相速度の増加により、波の発生位置が下流側へ移 動するためと考えられる。このように、気相がほ ぼ均等に分配されても、液相は必ずしも均等分配 にならないことが分かる。

分岐管背圧を均一にした Case B の場合、 $j_{g}$ の増 加に伴い気液ともに下流側分岐管での分配率が 増大寸る傾向は Case A と同様であるが、気相分 配の上流側分岐管への偏りは Case A に比べて著 しい。また液相分配率もCase A より上流側の分 岐管でピークに達している。Case B で測定された 合流タンクとヘッダ入口直前位置の間の圧力差 は、Case A における第 1 分岐管の背圧とヘッダ入 口直前の圧力との差に比べて大きな值を示して いた。すなわち、Case B の第 1 分岐管前後におけ る差圧は Case A における差圧に比べて大きいと 推定され、これが Case B で観察された気相分配 の上流側分岐管への偏りに対応すると考えられ る。この気相分配を受けて、ヘッダ内の気相流速 は下流域で急速に減少する。その結果、気液界面 における波の発生位置は Case A に比べて上流側に

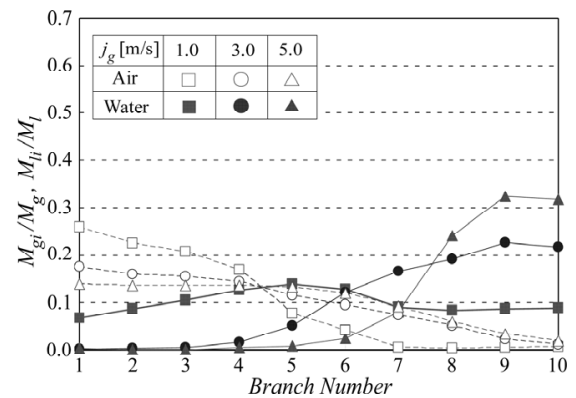

(a) Case $\mathrm{A}$

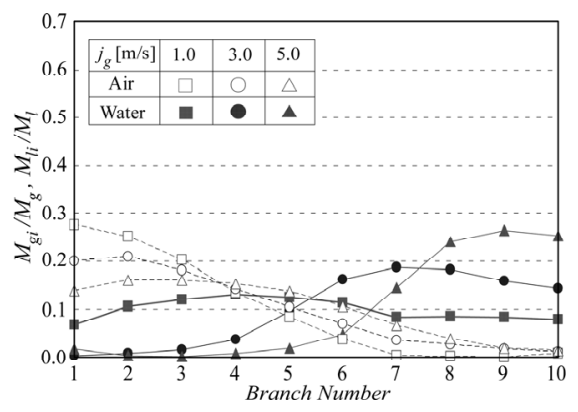

(b) Case B

Fig. 7 Flow distributions for stratified-flow inlet (Multi-port tube branches, $j_{l}=0.03 \mathrm{~m} / \mathrm{s}$ ).

移動し、またヘッダ下流域に滞留した液相を分岐 管へ押し上げる慣性力も得られなくなるため、液 相分配は Case A に比べて上流側の分岐管で増大 するものと考えられる。

Fig. 7 に多孔分岐管における気液分配率を示す。 なお、Case A における各分岐管の背圧は Fig. 6 の結果と定量的によい一致を示した。両圧力条件 での気液分配を比較すると、Case B では Case A に比べて上流側分岐管への気相分配が増加し、下 流側分岐管の液相分配が減少する傾向を示すが、 両者の差は偏平分岐管で観察された差に比べて 小さい。すなわち、多孔分岐管の場合、分岐管の 背圧条件は気液分配特性に大きな影響は与えな い。これは、後述のように、微細多孔管の圧力損 失が偏平管に比べて大きいため、分岐管間の背圧 差の影響が相対的に減少したことによる。

多孔分岐管の気相分配率は、低 $j_{g}$ では上流側分 岐管で高い值を示すが、 $j_{g}$ が増加するにつれて下 流側分岐管における值も増加していく。また、液 相分配は $j_{g}$ の増加に伴い下流側分岐管へ偏るよ うになる。こうした分配特性は、偏平分岐管の Case A（不均一背圧）における結果と定性的に一 


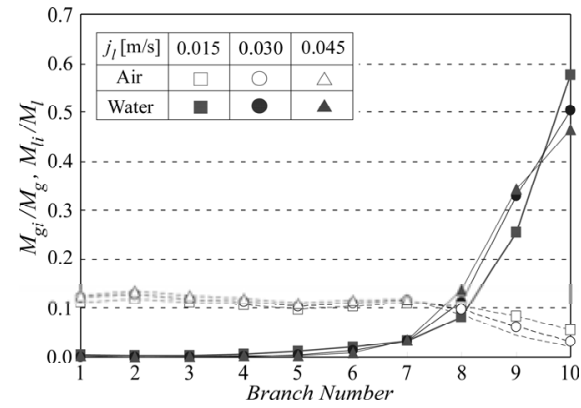

(a) Case $\mathrm{A}$

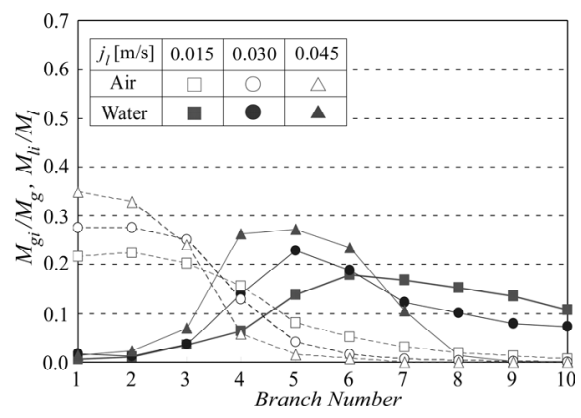

(b) Case B

Fig. 8 Flow distributions for stratified-flow inlet (Flat tube branches, $j_{g}=5 \mathrm{~m} / \mathrm{s}$ ).

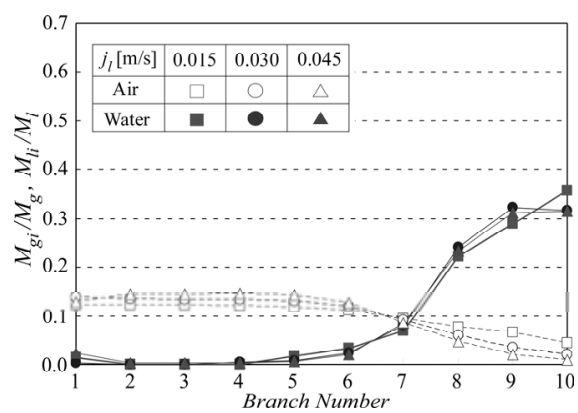

(a) Case $\mathrm{A}$

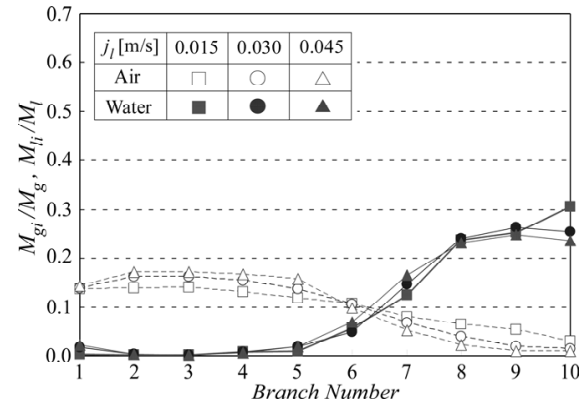

(b) Case B

Fig. 9 Flow distributions for stratified-flow inlet (Multi-port tube branches, $j_{g}=5 \mathrm{~m} / \mathrm{s}$ ).
致するが、高 $j_{g}$ における液相分配の下流側分岐管 への偏りは偏平分岐管に比べて緩和されている。

次に、気相見かけ速度 $j_{g}$ を $5 \mathrm{~m} / \mathrm{s}$ に固定し、液 相見かけ速度 $j_{1}$ を変化させた場合について述べる。 Fig. 8 は偏平分岐管における気液分配率であり、 (a)に Case A、(b)に Case B の結果を示す。Case A の場合、 $M_{g i} / M_{g}$ と $M_{l i} / M_{l}$ はともに $j_{l}$ に対してほ とんど変化せず、気相が第 8 分岐管までほぼ均等 分配されるのに対して、液相分配は下流側分岐管 に著しく偏る様子が観察される。一方、Case B で は $j_{1}$ の増加に伴い気相、液相ともに上流側分岐管 の分配率が高まる傾向を示す。しかし、Fig. 8(b) と Fig. 5(b)の比較から、偏平分岐管における気液 分配特性は、 $j_{l} よ り も j_{g}$ の影響をより強く受ける ことが分かる。一方、Fig. 9 に示した多孔分岐管 の気液分配には、分岐管の背圧条件や $j_{l}$ の影響は 認められず、分布傾向は偏平分岐管の Case A に おける結果と定性的に一致している。

\section{2 噴霧流入の実験結果}

本節では、ヘッダ入口における気液流入条件を 層状流入から噴霧流入一変えた影響について検 討する。Fig. 2(b) に示したように、噴霧流入の場 合、ヘッダ入口近傍では液滴が壁面に付着し流れ は環状噴霧流となるが、 $j_{g}$ が低い場合には下流域 で気液が上下に分離する傾向が観察された。しか し、層状流入の場合に観察されたような大規模な 波の発生は認められなかった。

Fig. 5 と同様に $j_{l}$ を $0.03 \mathrm{~m} / \mathrm{s}$ に固定し $j_{g}$ を変 化させた場合について、偏平分岐管で得られた気 液分配特性を Fig. 10 に示す。(a)は不均一背圧の Case A、(b)は均一背圧の Case B における結果で ある。Case A では、気相分配は Fig. 5(a)の層状流 入における結果と類似であり、 $j_{g}$ の増加に伴い気 相は均等分配に近づいている。液相は高 $j_{g}$ 時に分 布の均一性が層状流入に比べて高まっているが、 $j_{g}$ が最も低い $1.0 \mathrm{~m} / \mathrm{s}$ の場合には、第 4 から第 7 分岐管で $M_{l i} / M_{l}$ は非常に低くなっている。この条 件では、ヘッダ入口近傍で上壁面に形成された液 膜は上流域の分岐管から排出され、ヘッダの中央 部分において液は主に底面上を流れるため分岐 管には流入しにくくなる。より下流の領域では、 ヘッダに充満した液が分岐管から排出されるた め、 $M_{l i} / M_{l}$ は再び高い值を示すようになる。気相 速度が増加すると、液滴が気相によってより下流 域にまで輸送されるため、液相分配は比較的均一 


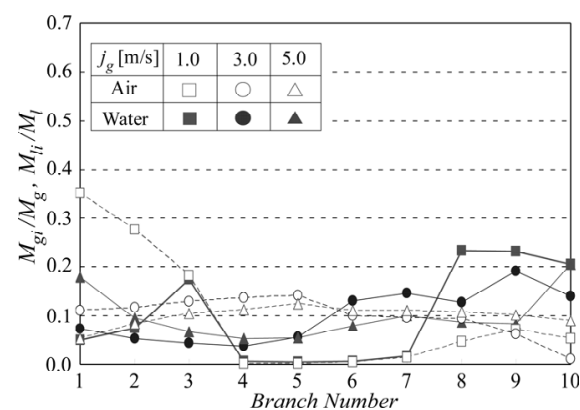

(a) Case $\mathrm{A}$

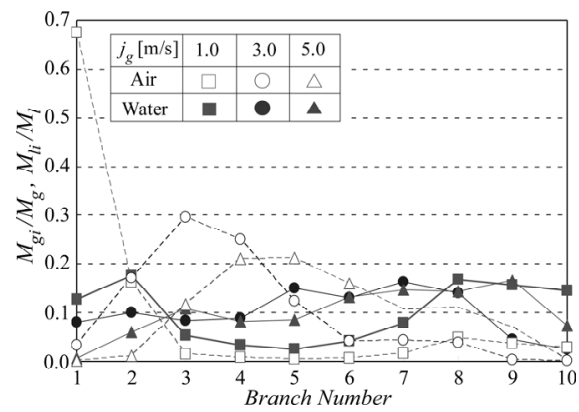

(b) Case B

Fig. 10 Flow distributions for mist-flow inlet (Flat tube branches, $j_{l}=0.03 \mathrm{~m} / \mathrm{s}$ ).

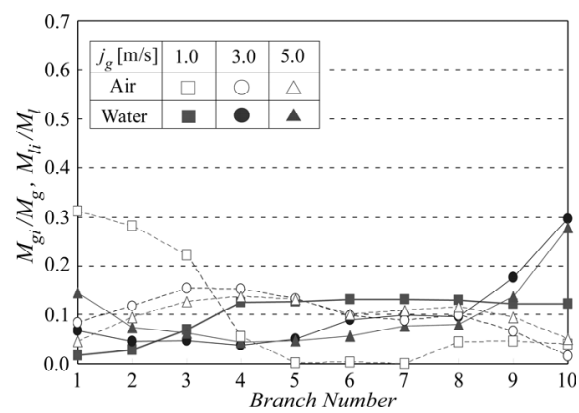

(a) Case $\mathrm{A}$

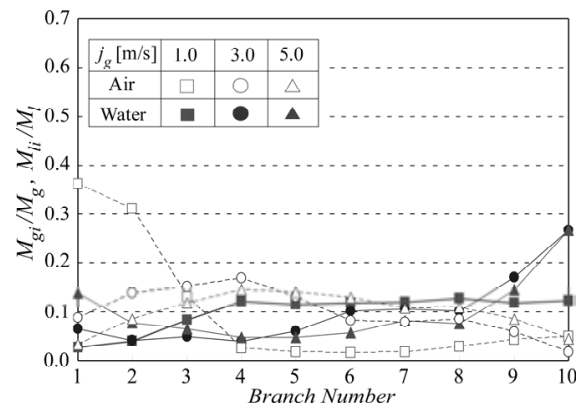

(b) Case B

Fig. 11 Flow distributions for mist-flow inlet (Multi-port tube branches, $j_{l}=0.03 \mathrm{~m} / \mathrm{s}$ ).
性の高い分布を示すと考えられる。

Case B の場合、低 $j_{g}$ 時の気相分配は層状流入と 同様に上流側分岐管に著しく偏るが、 $j_{g}$ の増加に 伴い下流域での $M_{g i} / M_{g}$ が増加するため、層状流 入に比べて気相分配の均一性は高まる。しかし、 Case A に比べると上流側分岐管における気相分 配率が全般に高い傾向を示し、高 $j_{g}$ 条件下でも Case A で見られたような均一性の高い気相分配 率分布は得られない。一方、液相分配率は Case A の結果と定性的に一致した傾向を示し、高 $j_{g}$ 条件 下では比較的均一な分布を示す。

Fig. 11 に多孔分岐管における結果を示す。層 状流入の場合と同様に、多孔分岐管の場合には分 岐管の背圧条件が気液分配に及ぼす影響は非常 に小さい。気相分配は、上に述べた偏平分岐管の Case A における結果とほぼ一致している。液相分 配も $j_{g}=1.0 \mathrm{~m} / \mathrm{s}$ 以外の場合は同様であり、また $j_{g}$ $=1.0 \mathrm{~m} / \mathrm{s}$ では層状流入時に比べて液相分配の均 一性が向上している。

$j_{g}$ を固定し $j_{l}$ を変化させた場合については、紙 数の制限のため詳細な結果は示さないが、偏平分 岐管の Case B では $j_{l}$ の増加に伴い上流側分岐管 で気液とも高分配率を示寸傾向が認められた。一 方、偏平分岐管の Case A と多孔分岐管の結果は 定性的に一致し、気相は $j_{l}$ にかかわらず均一性の 高い分布を示すが、液相は $j_{l}$ の増加に伴い下流側 分岐管への分配が増加する傾向を示した。

\section{3 液相分配の均一性の評価}

以上に示してきたように、多分岐管における気 液分配特性はヘッダ入口における流入条件や分 岐管出口の圧力条件、また分岐管の圧力損失特性 により複雑に変化する。本節では、エバポレータ でとくに重要となる液相分配の均一性を定量的 に評価するために、次式で定義される $M_{l i} / M_{l}$ の標 準偏差居を求めてみた。この值が小さいほど、分 岐管への液相分配の均一性が高いといえる。

$$
\sigma_{l}=\sqrt{\sum_{i=1}^{N}\left(\frac{M_{l i}}{M_{l}}-\frac{1}{N}\right)^{2} / N} \quad(N=10)
$$

Fig. 12 は層状流入の条件で得られた $\sigma_{l}$ の $j_{g}$ に 対する変化であり、図中には各 $j_{l}$ における偏平分 岐管（破線）と多孔分岐管（実線）の結果が比較 して示してある。図の(a)と(b)は Case A と Case B に対応している。多孔分岐管の $\sigma_{l}$ は背圧条件にか 


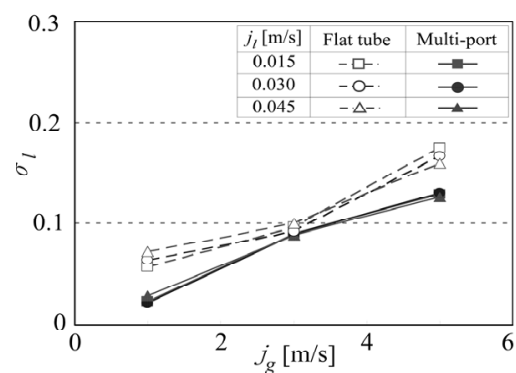

(a) Case $A$

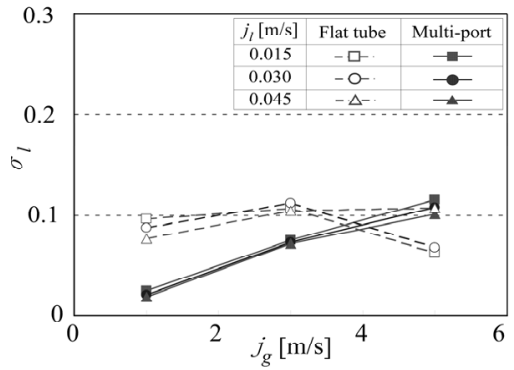

(b) Case B

Fig. 12 Standard deviations of the water distribution ratios $\sigma_{l}$ at stratified-flow inlet.

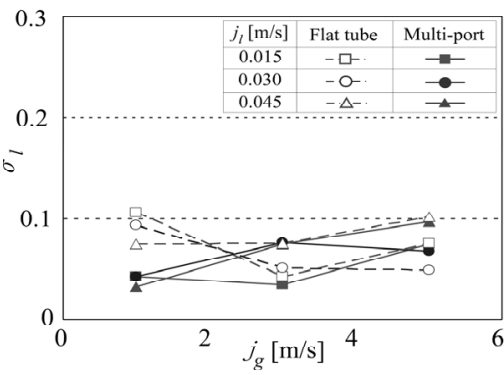

(a) Case $\mathrm{A}$

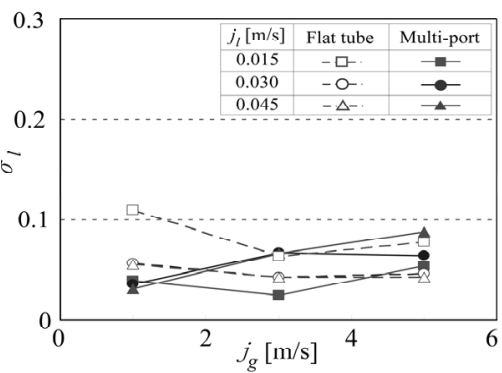

(b) Case $\mathrm{B}$

Fig. 13 Standard deviations of the water distribution ratios $\sigma_{l}$ at mist-flow inlet.

かわらず $j_{g}$ に対し単調に増加しているが、その值 は偏平分岐管に比べて全般に小さく、液相分配の 均一性が向上しているといえる。Fig. 13 は噴霧 流入における結果である。 $\sigma_{l}$ には分岐管背圧条

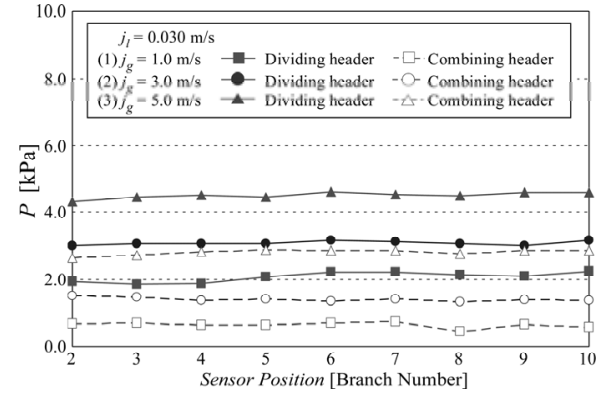

(a) Flat tube branches

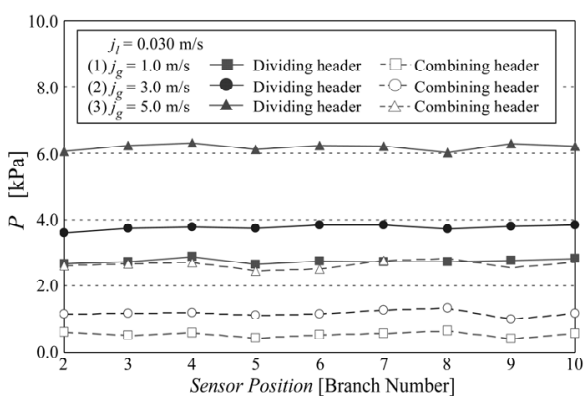

(b) Multi-port tube branches

Fig. 14 Pressure distributions in headers

(Stratified-flow inlet, $j_{l}=0.03 \mathrm{~m} / \mathrm{s}$ )

件や分岐管の種類による顕著な差は認められな いが、とくに高 $j_{g}$ 域で Fig. 12 の層状流入におけ る值よりも小さくなる傾向を示している。これら の結果から、液相分配の均一性に対してはヘッダ における流動様式が重要であり、気液を噴霧流の 状態でヘッダに流入させることにより液相を均 等分配に近づけることができると考えられる。

\section{4 ヘッダ内の圧力分布}

ヘッダ内の圧力分布には流入条件による差が 認められなかったため、ここでは層状流入での結 果を示す。Fig. 14 (a) と (b) は偏平分岐管と多孔 分岐管に対応し、いずれも $j_{l}$ を $0.03 \mathrm{~m} / \mathrm{s}$ に固定し $j_{g}$ を変化させた場合の結果である。実線が上流側 ヘッダ (Dividing header)、破線が下流側ヘッダ (Combining header) の圧力分布を示す。図の横 軸はセンサ設置位置に対応した分岐管の番号を 表している。なお、第 1 分岐管に対応寸る位置て は圧力測定を行わなかった。また測定は Fig. 4 の Reverse flow と Parallel flow について行ったが、 両者の結果は一致したため、ここでは Parallel flow における結果を示す。

両ヘッダ内の圧力は、 $j_{g}$ の值や分岐管の種類に かかわらず管軸方向にほぼ一定の值を示してい 


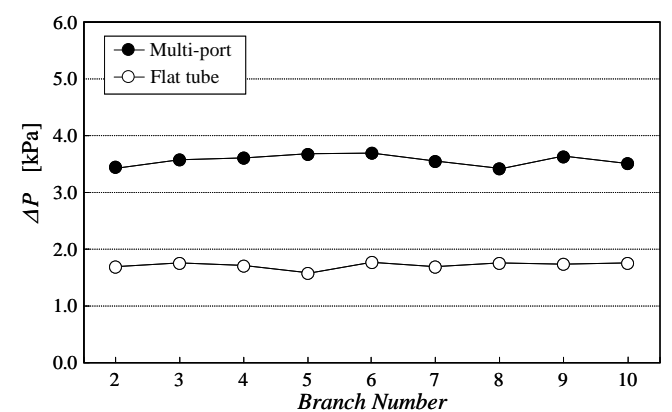

Fig. 15 Pressure difference between headers

(Stratified-flow inlet, $j_{g}=5.0 \mathrm{~m} / \mathrm{s}, j_{l}=0.03 \mathrm{~m} / \mathrm{s}$ ).

る。すなわち、エバポレータ実機においては、分 岐管出口の圧力条件は均一背圧の状態にあると 考えられる。この結果から、気液分配率を測定す る場合には、分岐管出口における圧力条件として Fig. 2(b) の Case B に相当する均一背圧条件を課 すことにより、エバポレータ実機に近い気液分配 状態を再現できると考えられる。とくに、偏平分 岐管の場合には気液分配特性は背圧条件にも強 く依存するため、分配率測定時における分岐管出 口の圧力条件には十分な注意を払う必要がある。

Fig. 15 は、Fig. 14 の結果から求めた両ヘッダ 間の圧力差分布の一例であり、各分岐管前後の差 圧に相当している。本結果と Case A で測定され た分岐管の背圧分布（Fig. 6）を比較すると、偏 平分岐管の場合、分岐管間の最大背圧差は Fig. 15 の分岐管差圧と同程度であるため、気液分配特性 には分岐管の背圧条件の影響が強く現れたと考 えられる。一方、多孔分岐管における分岐管差圧 は、最大背圧差の 3 倍程度に達している。すなわ ち、多孔分岐管では分岐管間の背圧差は分岐管前 後の差圧に比べて小さく、そのため気液分配特性 に及ぼす背圧条件の影響も偏平分岐管の場合に 比べて弱まったものと考えられる。

\section{4. 結言}

本研究では、垂直上昇多分岐管内の気液二相分 配に及ぼすへッダ入口の流入条件、分岐管出口の 圧力条件、および分岐管の圧力損失特性の影響に ついて調查し、以下の知見を得た。

(1) 層状流入の場合、偏平分岐管の気液分配は分 岐管背圧の影響を強く受け、不均一背圧では 液相が下流側分岐管に偏って分配されるのに 対し、均一背圧条件では上流側分岐管におけ
る液相分配が増大寸る。多孔分岐管では背圧 の影響は現れず、高 $j_{g}$ 時に液相分配は下流側 分岐管で増大するが、分布の偏りは偏平分岐 管に比べて緩和される。

（2）噴霧流入の場合、いずれの分岐管においても 背圧条件が分配特性に及ぼす影響は層状流入 ほど顕著ではない。液相分配は、とくに高 $j_{g}$ 条件で、分布の均一性が層状流入の場合に比 べて向上する。また、いずれの流入条件にお いても、多孔分岐管では偏平分岐管の不均一 背圧の場合と類似な気液分配特性を示す。

(3) 両ヘッダ内の圧力は、ヘッダ入口流入条件や 分岐管の種類にかかわらず、流動方向にほぼ 一定值を示す。このことから、気液分配率測 定時に課す分岐管出口の圧力条件としては、 均一背圧条件が妥当といえる。

\section{Nomenclature}

$j \quad$ : superficial velocity at the header entrance $[\mathrm{m} / \mathrm{s}]$

$M$ : mass flow rate at the header entrance $\quad[\mathrm{kg} / \mathrm{s}]$

$M_{i}$ : mass flow rate in the $i$ th branch $\quad[\mathrm{kg} / \mathrm{s}]$

$P_{c h}:$ pressure in the combining header $\quad[\mathrm{Pa}]$

$P_{d h}:$ pressure in the dividing header $\quad[\mathrm{Pa}]$

$P_{i}$ : pressure at the outlet of $i$ th branch $\quad[\mathrm{Pa}]$

\section{Greek letter}

$\sigma \quad$ : standard deviation of distribution ratios

\section{Subscripts}

$g$ : gas phase

$l \quad$ : liquid phase

\section{参考文献}

[1] Nakamura, T., Kuroyanagi, I., Kamiya, S. and Ohara, T., Ultra-Thin and Light-Weight RS Evaporator, SAE paper 2003-01-0527 (2003).

[2] Watanabe, M., Katsuta, M. and Nagata, K., Two-phase Flow Distribution in Multi-pass Tube Modeling Serpentine Type Evaporator, Proc. ASME/JSME Thermal Engineering Conf., Vol. 2, 35-42 (1995).

[3] Watanabe, M., Katsuta, M., Nagata, K., Sakakura, S. and Iijima, H., Two-phase Refrigerant Flow Distribution in a Multipass Evaporator with Vertical Upward Main Tube (1st report: Equal Heating Load on Each Pass), Tras. JAR., Vol. 13 (3), 277-284 (1996).

[4] Watanabe, M., Katsuta, M., Nagata, K., Sakakura, S. and Iijima, H., Two-phase Refrigerant Flow Distribution in a Multipass Evaporator with Vertical Upward Main Tube (2nd report: Unequal Heating Load on Each Pass), Tras. JAR., Vol. 13 
(3), 285-291 (1996).

[5] Bernoux, P., Mercier, P. and Lebouche, M. Two-phase Flow Distribution in a Compact Heat Exchanger, Proc. 3rd Int. Conf. Compact Heat Exchanger, 347-352 (2001).

[6] Vist, S. and Pettersen, J., Two-phase Flow Distribution in Compact Heat Exchanger Manifolds, Experimental Thermal Fluid Science, Vol. 28, 209-215 (2004).

[7] Koyama, S., Kuwahara, K., Miyazaki, H., Wijayanta, A. T. and Ikuta, S., Experimental Study on Refrigerant Flow Characteristics inside an Evaporator Header, Proc. 2004 JSRAE Annual Conf., A313-1 - A313-4 (2004).

[8] Ahmad, M., Berthoud, G. and Mercier, P., General Characteristics of Two-phase Flow Distribution in a Compact Heat Exchanger, Int. J. Heat Mass Transfer, Vol. 52, 442-450 (2009).

[9] Osakabe, M., Hamada, T. and Horiki, S., Water Flow Distribution in Horizontal Header Contaminated with Bubbles, Int. J. Multiphase Flow, Vol. 25, 827-840 (1999).

[10] Lee, J. K. and Lee, S. Y., Distribution of Two Phase Annular Flow at Header-channel Junctions,
Experimental Thermal Fluid Science, Vol. 28, 217-222 (2004).

[11] Marchitto, A., Devia, F., Fossa, M., Guglielmini, G. and Schenone, C., Experiments on Two-phase Flow Distribution inside Parallel Channels of Compact Heat Exchangers, Int. J. Multiphase Flow, Vol. 34, 128-144 (2008).

[12] Kim, N-H. and Han, S-P., Distribution of Air-water Annular Flow in a Header of a Parallel Flow Heat Exchanger, Int. J. Heat Mass Transfer, Vol. 51, 977-992 (2008).

[13] Katsuta, M., Yamagata, K. and Fukai, K., Distribution Characteristics of Two-phase Gas-liquid Flow in Horizontal Multipass Tube The Effect of Branch's Local Geometry, Proc. 2009 JSRAE Annual Conf., 551-554 (2009).

[14] Lee, S. Y., Flow Distribution Behavior in Condensers and Evaporators, Proc. 13th Int. Heat Transfer Conf., KN-08, CD-ROM (2006).

[15] Kuwahara, K., Kazari, K., Nakashita, K. and Koyama, S., Experiment on Flow Boiling of HFC 134a in a Multi-port Extruded Tube, Trans. JSRAE, Vol. 21, 121-128 (2004). 